\title{
Development of Web-Based English Proficiency Test Model for EFL Classroom
}

\author{
Hasan Ayuba (Corresponding Author) \\ hasanayuba@iaingorontalo.ac.id \\ IAIN Sultan Amai Gorontalo, Indonesia \\ Aleeyah Masae \\ aleeyah.m@yru.ac.th \\ Yala Rajabhat University, Thailand
}

\begin{abstract}
The digital transformation of higher education institutions is a critical concern that several stakeholders in education must address; however, abilities to apply ICT in all spheres of life are still evolving, most notably Web-based tests to assess students' English proficiency. This research aims to produce a Web-Based English proficiency test for the English Education Study Program in State Institute of Islamic Studies (IAIN) Sultan Amai Gorontalo. The type of this research was Research and Development (R\&D). The researcher modified Borg and Gall's development research model, which consisted of five steps:(1) evaluation of material and media experts, (2) one-on-one trial, (3) small group trial, (4) field trial, and (5) the final product.The evaluation was conducted by a media and material expert. The trial subjects consisted of 40 students: 12 students of one-to-one trial, 20 students of small group trial, and 40 students of field trial (including those in one-to-one and small group trial students). The data collection instrumentsused was an evaluation sheet for material expert, media expert, and a questionnaire for students involved in the display and the web system aspects. The data were analyzed by using descriptive quantitative, and qualitative techniques. The research result revealed that the Web-Based Test of English proficiency for English Program,developed determined by the media expert, indicated that the web display aspect assessed "good" $(4,07)$. Meanwhile, the evaluation result from media expertsshowed from the system aspect considered "good" $(4,10)$. The final product of this research was a web-based test for English Proficiency with the domain address www.eptestee.or.id.
\end{abstract}

Keywords: Web-based; English proficiency; English program

\section{A. INTRODUCTION}

Online learning has become more critical due to the widespread acceptance of the World Health Organization's social distancing policy, which was announced as a measure to fight the spread of Covid-19 and has pushed schools and universities to stop 
all their activities. The State Institute of Islamic Studies Sultan Amai Gorontalo is one of the institutes affected by the Covid-19 virus outbreak.

The most noticeable impact is the shift in learning strategies and methods previously carried out face-to-face but must now be carried out online. Therefore, the Lecturers should be more adaptable to online learning applications for the lecture process to run smoothly. Considering that the courses taught are skills, the English Education Department (Later known as The Department) moves quickly by utilizing existing online learning platforms such as zoom, Google meet, Google classroom, and other similar applications.

However, the Department must run one program and requires active participation from lecturers and students, namely the English Program. Overall, the learning process for the evaluation went smoothly. However, problems occurred when most students complained that their grades did not match their abilities. After The Department reevaluated the program, the issues discovered that the source of the problem was the use of online exam applications. The Department used Google forms to conduct the test, which meant that the students were not well controlled. Some students were still asking questions and searching for answers on the Internet.

In terms of assessment effectiveness, one of the most visible and tangible aspects is the use of technology as a medium for online assessment ( $\mathrm{Qu} \&$ Zhang, 2013). The Internet is a cutting-edge technical medium that can assist classroom learning with all its benefits. The Internet has made access to authentic materials, vast linguistic resources, and an exhaustive range of materials in all languages easier (Ciptaningrum, 2017). Moreover, the technology dominates the daily lives of people interaction, how the lecturers can leverage those interactions to the benefit of the students, and how we can engage them in learning experiences to encourage them to practice language extensively (Kessler, 2018). One of the technology goals is to take advantage of the potential of web-based tests (WBTs) to expand the assessment quality. The Department should make excellent use of the technology-based test to enhance the online test process in English Program.

Some web-based test systems have been developed for the same purpose, such as WES (Web-based Examination System) that can serve as an effective solution for mass education evaluation and offers many novel features that cannot be implemented in paper-based systems, such as real-time data collection, management, and analysis, 
distributed and interactive assessment towards promoting distance education (Abass et al., 2017). Furthermore, Barekar et al (2021) published the results of their research, which discussed the use of the online test system. This study focuses more specifically on the practicality of online tests. Online test results can be taken at any time and do not require higher costs than traditional exam scenarios, as no documents are required (e.g., printing out testpapers, preparing documents for admission). The online test fee will be almost zero once the online test system is set up and if maintenance costs are not considered.The more specific research conducted by Rokhaniyah \& Putra (2021), webbased testing revealed that web-based online test could optimize learners' excitement to assess their IELTS proficiency.

Due to the description of the problem and the results of scientific research related to the implementation of online tests, the researcheris interested in developing a web-based online test system. The distinction between this research and the prior studies is in the investigation's focus. For example, Bodmann\& Robinson's research focuses only on comparing web-based and paper-based tests. In comparison to Bodmann\& Robinson, Praful Barekar focuses on the feasibility of administering the web-based test. Furthermore, Rokhaniah focuses on how IELTS competency can maximize students' enthusiasm for reading.

Meanwhile, this research is focused on developing a web-based standardized test system.Therefore, the Web-Based Test (WBT) development is expected to help overcome the student's English proficiency test implementation. Furthermore, this WBT can be used to complete the basic, intermediate, and advanced levels.

Based on the research background, the problems in the research can be formulated as follows: "How to Develop a Web-Based Proficiency Test Model for English Programs in the Department of English Education with quality in terms of material, web display, and system aspects?"

\section{B. RESEARCH METHOD}

\section{Development Model}

In this study, the researcher used the Borg \& Gall (1988) development model and adapted it to the researcher's development steps. The following is a description of the model. 


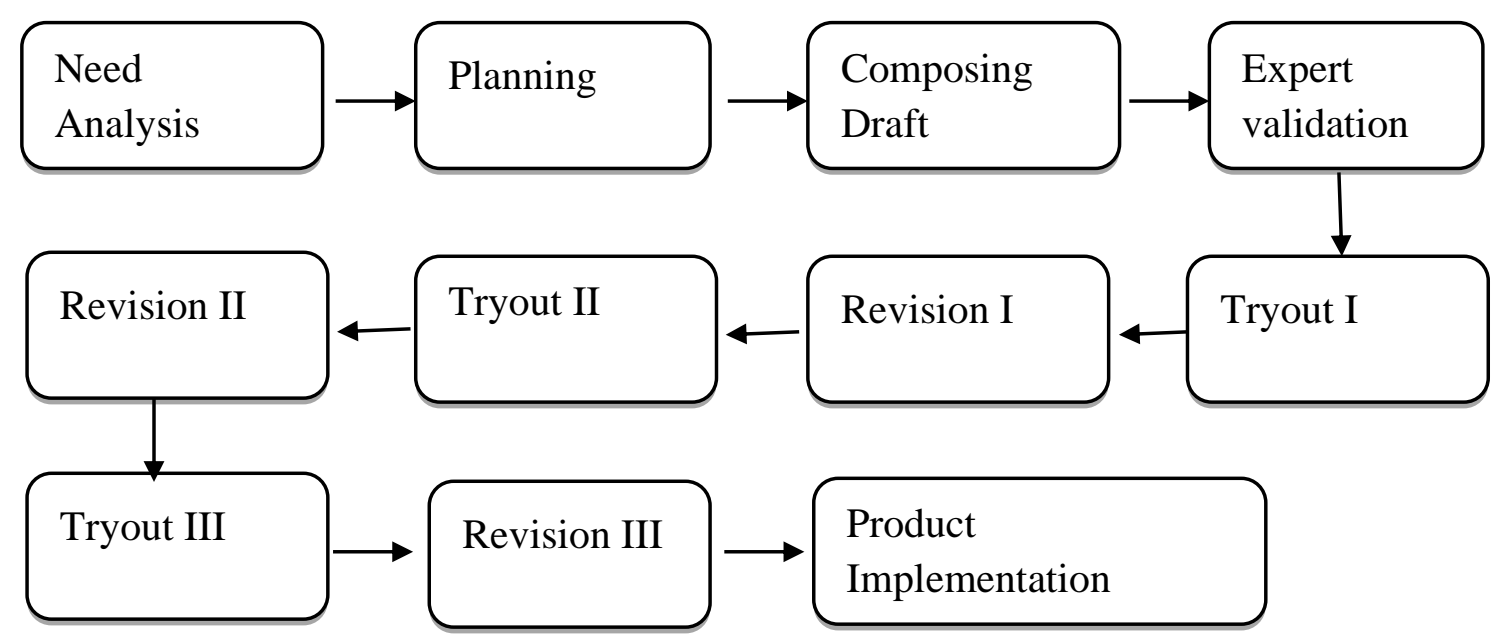

\section{Chart1. Borg \& Gall development Model}

Meanwhile, the researcher used McIntire's (2000) model development test. McIntire proposed ten stages for test development (2000). However, in this research, only four stages of the test development plan are written: planning the test development, arranging the question items, doing the small-scale trial, and revising the test. The stages are presented in Chart 2 below:

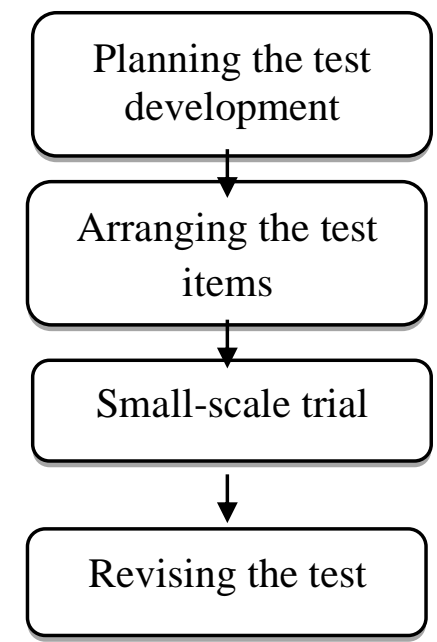

\section{Chart 2. The stages of the test development}

These four stages were chosen because several steps in developing the test could be combined.

\section{Development Procedure}

Web-Based Test development research procedures for the English program consisted of five stages. They were: (1) needs analysis, (2) product development planning, (3) product development, (4) product evaluation stages, and (5) final product. 
The first was the needs analysis. This process included a literature review and a field study. A literature review was conducted to gather information about which aspects of competence were included in a Web-based test. The literature review was carried out by reading the English education department's curriculum, syllabus, and test material-related textbooks, books on the theory that underpins web development, journals, and reports on research results on the use of the web in assessment. Meanwhile, Observations and interviews were both included in field studies. The observations were conducted to ascertain the Department's current state, particularly internet connectivity and computer facilities in the language lab. Meanwhile, the interviews were used to elicit more detailed information about students' and lecturers' readiness to accept and use a web-based assessment system and their access to resources (access to computers and the Internet).

The second was product development planning. After going through a series of literature and field studies, the next stepswere: the first, planning test development. At this point, the researcher developed a grid of questions and a scoring system. The test construct was generated by analyzing the fundamental competencies or components of the theory/test material under consideration. The second step involved creating test items. The researcher organized questions according to the grid of previously composed questions at this stage. The final step involved validating the reviewer's questions. The reviewer assessed the material, construction, and language aspects.

The third was product development. In this section, there were four steps to be done. The first was constructing a flowchart outlining the web design process. The second step was collecting the supporting materials. The third step was to package the English proficiency test into the web. The final step was producing the product.

The fourth stage was product evaluation. After developing the product, the researcher distributed the evaluation sheets to material experts, media experts, and research subjects. The students determined the product's feasibility as the research subjects in one-on-one trials, small group trials, and large group trials. The fifth was the final product. The final product was a media ready to use as a web-based English proficiency test in the English Program.

\section{Research Subjects}

The subjects of this research were 40 students of the English Education Department IAIN Sultan Amai Gorontalo. They were 12 students for a one-on-one trial, 20 students 
for a small-scale trial, and 40 students (including one-on-one and small-scale trial subjects) for a wide-scale test (field test). However, the selection of the subjects in this research was determined by random sampling because the topics selected had relatively diverse knowledge and competencies of English.

\section{Data Collection Techniques and Research Instruments}

The researcher collected research data through expert evaluation sheets and questionnaires. The evaluation sheet was used to measure and assess the quality of the product from the material, web appearance, and system aspect, which was completed by both web and material experts. Meanwhile, the questionnaire sheets measured and evaluated product quality from the displays and the system's components. The last instrument was Interview. It was used to obtain in-depth data about research product quality from lecturers and students.

\section{Data Analysis Technique}

The data obtained from evaluating material, media, and product trials, including one-on-one, small group, and large group, were analyzed quantitatively. The results of the data analysis were used as a basis for revising the research product. The quantitative data collected through questionnaires were analyzed quantitatively and then converted to qualitative data using a five-point scale, as seen in Table 1.

Table 1. Score Conversion

(Adapted from Sukardjo, 2005: 53)

\begin{tabular}{ccc}
\hline Value & Scores & Criteria \\
\hline A & $X>X i+1,80 \mathrm{Sbi}$ & Very Good \\
B & $X i+0,60 S B i<X \leq X i+1,80 S B i$ & Good \\
C & $X i-0,60 S B i<X \leq X i+1,80 S B$ & Enough \\
D & $X i-0,60 S B i<X \leq X i-1,80 S B$ & Less \\
E & $X \leq X i-1,80 \mathrm{Sbi}$ & Very Less \\
\hline
\end{tabular}

The conversion guideline above was used to determine the eligibility criteria for the research product. The product for the English Program was considered feasible as a media or test tool if the results of the field trial assessment were included in good criteria (B).

In this research, a minimum product feasibility value of "B" was determined, with the "Good" category, as a result of assessments from material experts, web experts, and students. If the final assessment results of all aspects had a minimum score of "B" (Good), then the research product was suitable forthe English Proficiency Test in the English Program at English Education Department IAIN Sultan Amai Gorontalo. 


\section{FINDINGS AND DISCUSSION}

\section{Findings}

This section presents the descriptions of need analysis, initial product development, product evaluation, and the analysis of trial products.

\section{The Descriptions of Need Analysis}

Needs analysis is divided into two stages: literature study and field study. The data obtained through the literature study results from an analysis of the material used in the learning process in the English Education Department. The analysis then becomes the basis for preparing a grid of questions and a set of tests. Furthermore, the researcher distributes the observation sheets and questionnaires to lecturers and students at the English Education Department in the field study. The Observation aims to get the actual situation of the English Education Department in real-time, particularly the availability of internet connections and computer facilities in the language lab. Moreover, the questionnaire incites information about students' and lecturers' readiness to accept and use a web-based test system and access to resources (availability of computers and the Internet). The questionnaire results indicated that students and lecturers were ready and able to use the Web-Based Test as a medium for the English proficiency test in English Program.

\section{The Descriptions of Initial Product Development}

The initial product produced is an English proficiency test consisting of basic, intermediate, and advanced levels.

\section{The Description of English Proficiency Test}

The English Proficiency Test is a multiple-choice test consisting of 40 questions divided into ten listening questions, fifteen grammar questions, and fifteen reading questions. The items are derived from the TOEFL questions in Bruce Rogers's (2004) book as the material used in the English Program's learning process.

\section{The Description Web-Based Test}

A programmer who developed the eptesteeis an expert in developing the system. The developed system comprises a front page, a registration page, a question page, and an exam results page. The web-based test is designed in HTML and PHP, and the database is MySQL, with the domain name www.eptestee.or.id. 
The home page is divided into four sections: about eptestee, our team, official guide, and contact. The "Home" button contains information about eptestee and their utility in online examinations. Meanwhile, the "about eptestee" button provides information about eptestee. The "our team" button contains a profile of the developer/researcher. The "official guide" button includes detailed instructions on using and operating the eptestee. Furthermore, the "contact" button consists of the institution's address and the researcher's contact information.

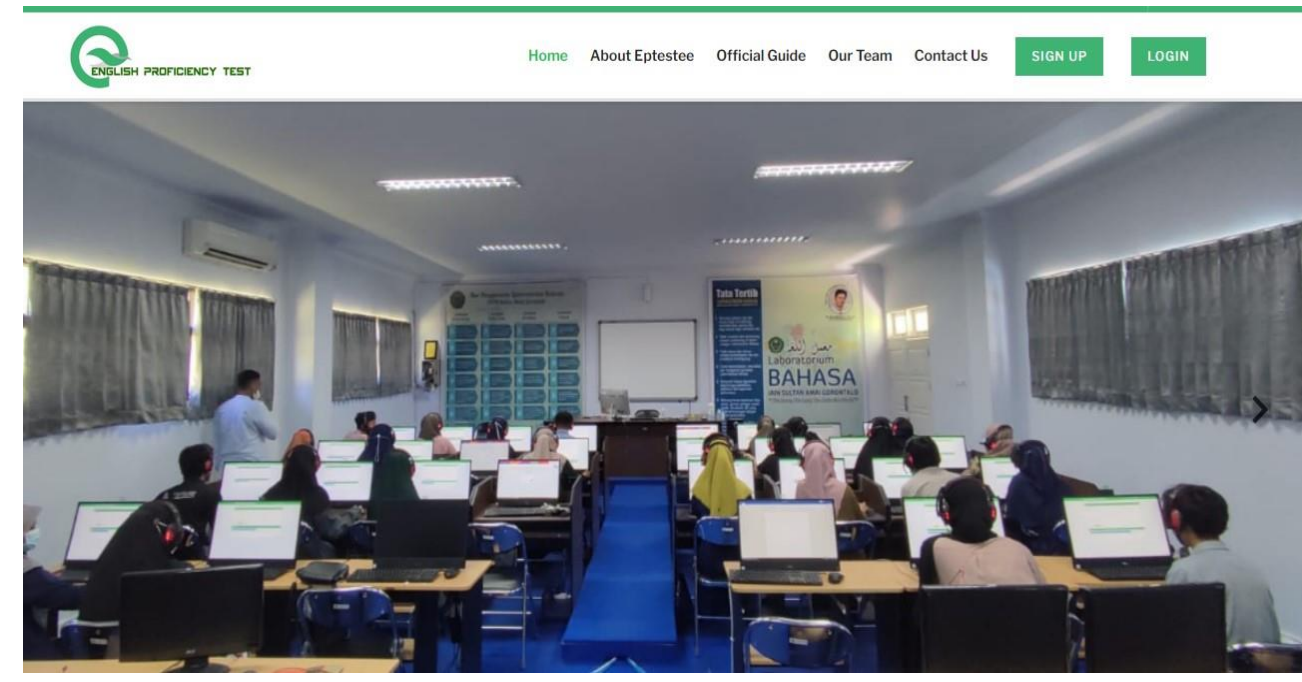

Picture 1. Home Page

\begin{tabular}{|lllll}
\hline ENGLISH PROFIIIENCY TEST & Home About Eptestee Official Guide Our Team Contact Us SIGN UP & LOGIN \\
\hline
\end{tabular}

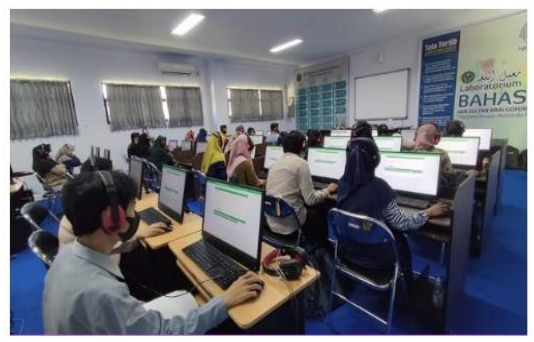

Welcome to the Eptestee.

Welcome to the Eptestee Official Guide for Test Takers! In this section, you will lear what the English Proficiency Test is, some advantages of taking the test, and how institutions use the test

The Eptestee is an English Proficiency test designed for you-convenient, fast, affordable, and trusted. The test is brought to you by Eptestee, the one of the popular way to assess your English proficiency online. Eptestee's aim is to develop your competence of English especially for the English Education Department students.

Picture 2. About eptestee Page 


\section{OFFICIAL GUIDE}

English Proficiency Test

\section{Official Guide}

- How To Test Your Best

Because you can choose when and where you take the test. you should take it when you feel your best mentally and physically.

Make sure you're comfortable and recharged

Plan to take the test at the time of day when you perform best. Sleep well the night before.

before the test.

Dest. But remember youcan's step away from (t) Have a brain-boosting snack

Read or watch something in English.
Test Structure

- Test length

You will need about 1 hour of uninterrupted tree time to take the English

Proficiency Test.

- About Computer Based Test

The Eptestee is a computer based test, which means that the question

(test has a tew differences than other tests you may have taken

Picture 3. Official Guide Page

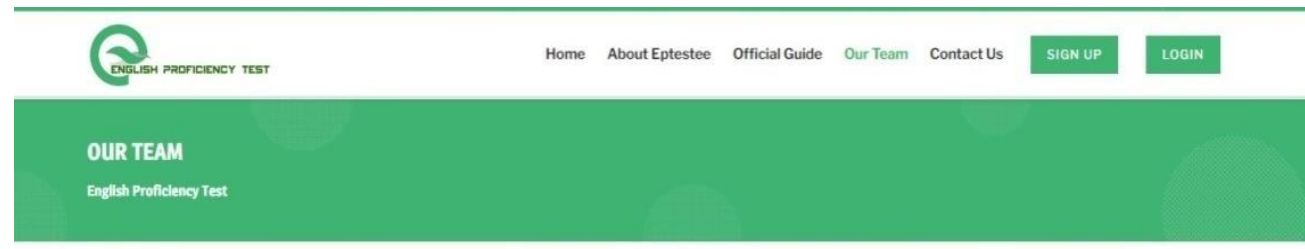

Hasan Ayuba, M.Pd.

HASAN AYUBA, M.PC.

About the Researcher

An English lecturer at English Education Department, Tarbiyah and Teacher Training

Faculty IAIN Sultan Amai Gorontalo with Master Education Degree graduation in the

field of Applied Linguistics in Yogyakarta State University. The main interest on the

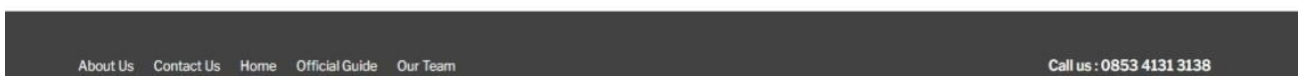

Picture 4. Our Team Page

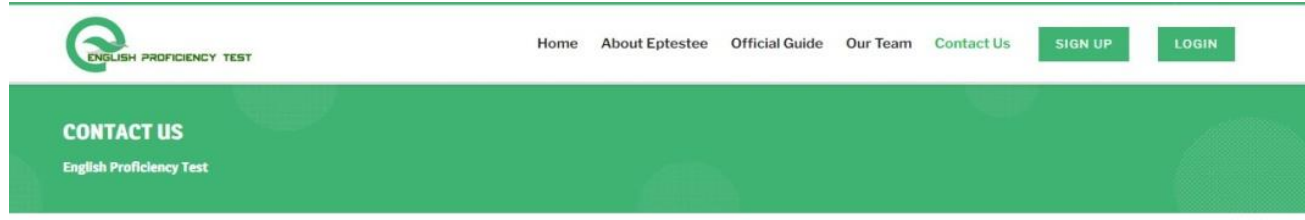

ENGLISH PROFICIENCY TEST

ALAMAT:

Il. Sultan Amay Pone Limboto Barat Kabupaten Gorontalo. Gorontalo 9618

TELPHONE:

0853-4131-3138 (Hasan Ayuba)

EMAlL:

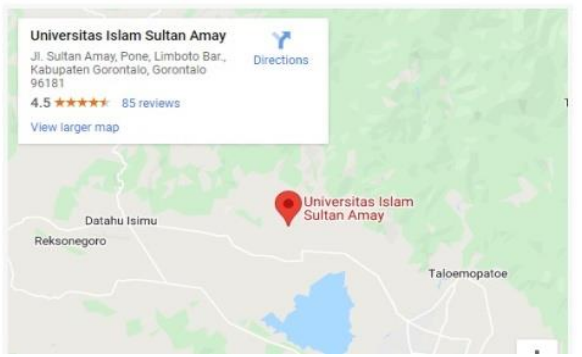

Picture 5. Contact Us Page 


\section{The Description of The Trial Product Analysis}

Several data sets were obtained in this research, including data from material expert evaluations, media expert evaluations, one-on-one trials (12 subjects), small group trials (20 subjects), and field trials (40 subjects). The information gathered results from material and media experts' responses and students to web-based English proficiency tests. The data obtained from material and media experts is then used to improve the product before being tested on a larger scale.

In evaluating products, materials experts and media experts play distinct roles. Material experts examine the presented questions' material, construction, and linguistic components. Meanwhile, media experts analyze the system's appearance and its operational characteristics.

Furthermore, one-on-one and small group trials were conducted to collect data as the foundation and reference for the product's revision. Additionally, the data collected during these stages is used to identify underlying issues that do not manifest themselves during field trials. The explanation of the steps is as follows:

\section{Material Evaluation Data Description}

At this stage, the material expert is given a previously prepared test (items from the English Proficiency Test) and a Likert scale questionnaire covering material, construction, and language aspects. The evaluation of the results is described on the following table:

Table 2. Material Aspect Evaluation by Material Expert

\begin{tabular}{|c|c|c|c|}
\hline No. & Indicators & Scores & Criteria \\
\hline \multicolumn{4}{|c|}{ Material } \\
\hline 1 & The suitability of the questions with the indicators & 4 & Good \\
\hline 2 & Deterrence function & 4 & Good \\
\hline 3 & Each question has one correct answer & 4 & Good \\
\hline 4 & $\begin{array}{l}\text { The suitability of the boundaries of the question and } \\
\text { the expected answer is clear }\end{array}$ & 4 & Good \\
\hline 5 & Suitability of questions with learning objectives & 5 & Very Good \\
\hline \multicolumn{4}{|c|}{ Construction } \\
\hline 6 & $\begin{array}{l}\text { The formulation of the subject matter is clear and } \\
\text { firm }\end{array}$ & 4 & Good \\
\hline 7 & $\begin{array}{l}\text { The formulation of the questions and the selection of } \\
\text { answers are only necessary statements }\end{array}$ & 4 & Good \\
\hline 8 & $\begin{array}{l}\text { The subject matter does not give a clue to the correct } \\
\text { answer }\end{array}$ & 4 & Good \\
\hline 9 & $\begin{array}{l}\text { The subject matter does not contain double negative } \\
\text { statements }\end{array}$ & 4 & Good \\
\hline 10 & Selection of homogeneous and logical answers in & 4 & Good \\
\hline
\end{tabular}


terms of material

11 The suitability of the length of the answer choice 4

Good formulation

12 The suitability of the answer choices that do not

Good contain the statement "All of the answer choices above are correct" or "All of the answer choices above are incorrect".

13 The suitability and functioning of images, graphs, tables, diagrams, and discourses contained in the questions

14 The item of the question does not depend on the answer to the previous question

\section{Language}

15 The suitability of each question with English 5 Very Good grammar

16 Use of communicative language 5 Very Good

17 The choice of answers does not repeal 5 Very Good words/phrases that are not a unified meaning

Total

Average Score

72

4,23

Based on the table, the material expert evaluation result is 4,23 , categorized as "very good." The result indicated that the test items are worth using as the English proficiency test.Furthermore, the indicators consisted of 17 statements as presented in the table. There are 4 statements $(23,53 \%)$ assessed "very good" and 13 statements (76,47\%) assessed "good". These results are clearly described on the chart below:

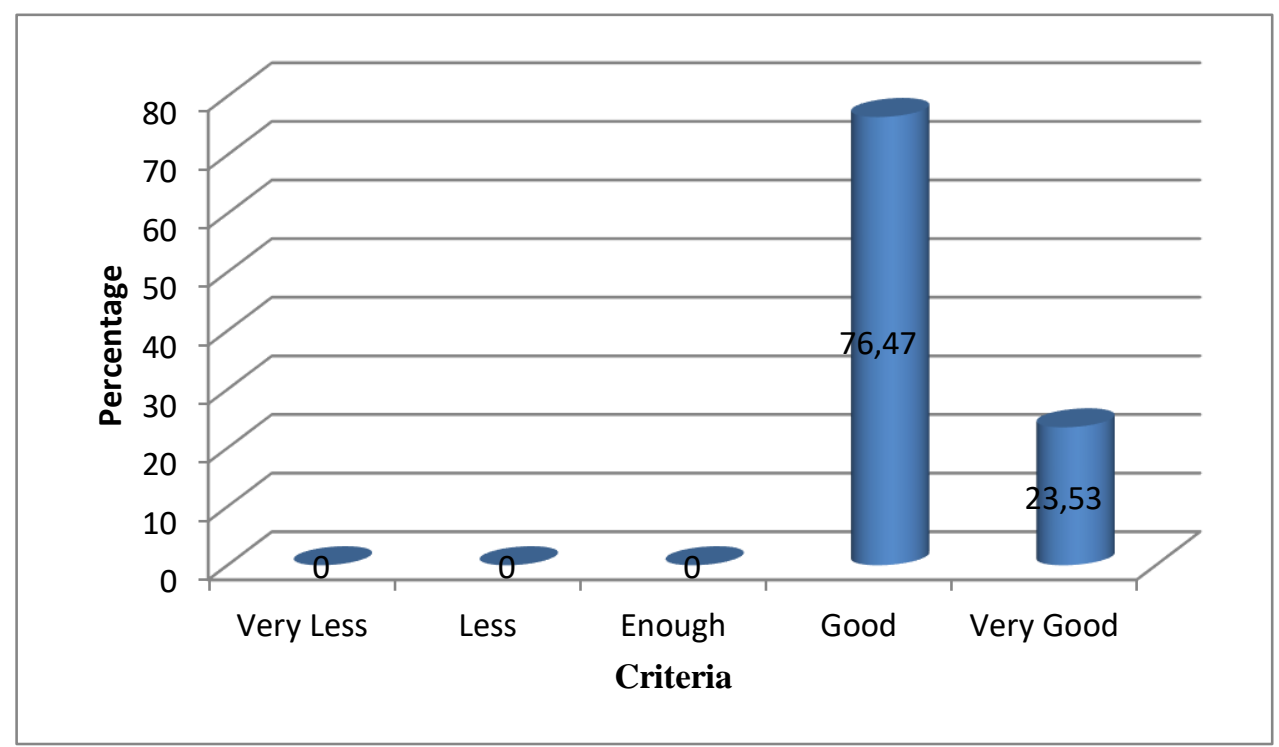

Chart 1.Material Aspect Evaluation Result

\section{Media Expert Evaluation Data Description}

In evaluating the web-based test, the media expertuses a questionnaire that includes two aspects: the web display and the web system. The expert evaluates the general view 
and presentation of questions that have been developed. The media expert's evaluation results can be seen in the following table.

Table 3. Display Aspect Evaluation

\begin{tabular}{|c|c|c|c|}
\hline No & Indicators & Scores & Criteria \\
\hline \multicolumn{4}{|c|}{ General Display } \\
\hline 1 & The Interesting home page design & 4 & Good \\
\hline 2 & Color selection accuracy on the login page & 4 & Good \\
\hline 3 & Text color selection accuracy & 4 & Good \\
\hline 4 & Font selection accuracy & 4 & Good \\
\hline 5 & $\begin{array}{l}\text { Color compatibility of the button with the } \\
\text { background }\end{array}$ & 4 & Good \\
\hline 6 & Button consistency & 4 & Good \\
\hline 7 & Button size accuracy & 4 & Good \\
\hline 8 & Button location accuracy & 4 & Good \\
\hline 9 & The attractiveness of the menu display & 4 & Good \\
\hline \multicolumn{4}{|c|}{ The Question Display } \\
\hline 10 & The accuracy of the text size used & 4 & Good \\
\hline 11 & Readability and Clarity of questions & 5 & Very Good \\
\hline 12 & The attractiveness of the text used & 4 & Good \\
\hline 13 & Match the text color used & 4 & Good \\
\hline 14 & $\begin{array}{l}\text { The attractiveness of the text color with the } \\
\text { background color used }\end{array}$ & 4 & Good \\
\hline \multicolumn{2}{|r|}{ Total } & 57 & Good \\
\hline \multicolumn{2}{|c|}{ Average Score } & $\mathbf{4 , 0 7}$ & \\
\hline
\end{tabular}

As seen in the table above, there are 14 indicators of display aspect evaluation. One indicator $(7,14 \%)$ is assessed "very good" from those indicators. Meanwhile, 13 arrows $(92,86 \%)$ are considered "good." The detailed analysis result is presented in the following chart.

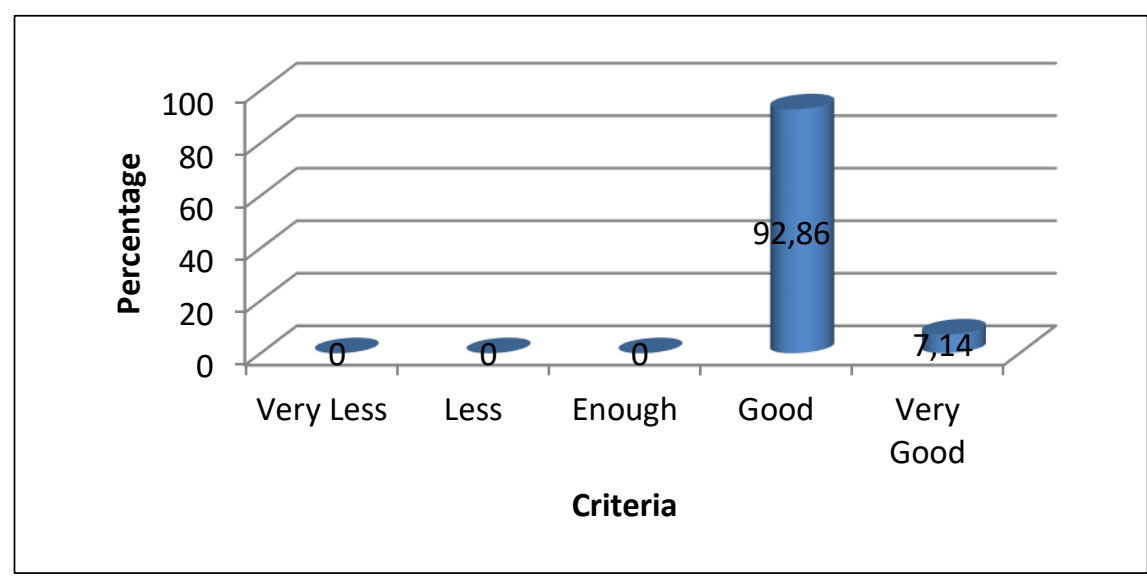

\section{Chart 2.Media Aspect Evaluation Result}

Meanwhile, in evaluating the web system, the expert focuses on various aspects of the web system. The result of the evaluation is presented in the following table. 
Table 4.Web System Evaluation

\begin{tabular}{clcc}
\hline No & \multicolumn{1}{c}{ Indicators } & Scores & Criteria \\
\hline 1 & Ease of using the system & 4 & Good \\
2 & Complete menu to support operations & 4 & Good \\
3 & Ease of selecting the menu on the system & 4 & Good \\
4 & Ease of interacting with the system & 4 & Good \\
5 & Easy to understand navigation structure & 4 & Good \\
6 & Key function speed (navigation performance) & 4 & Good \\
7 & Button reaction accuracy (navigator buttons) & 4 & Good \\
8 & Easy to use navigation for links between & 5 & Very \\
& components & & Good \\
9 & System security & 4 & Good \\
10 & Sufficient time during the exam & 4 & Good \\
& Total & $\mathbf{4 1}$ & \\
& Average Score & $\mathbf{4 , 1 0}$ & Good \\
\hline
\end{tabular}

Based on the table above, there are ten indicators of web system evaluation. One indicator (10\%) is assessed as "very good," and 9 indicators (90\%) are considered "good". The result is presented in the following chart.

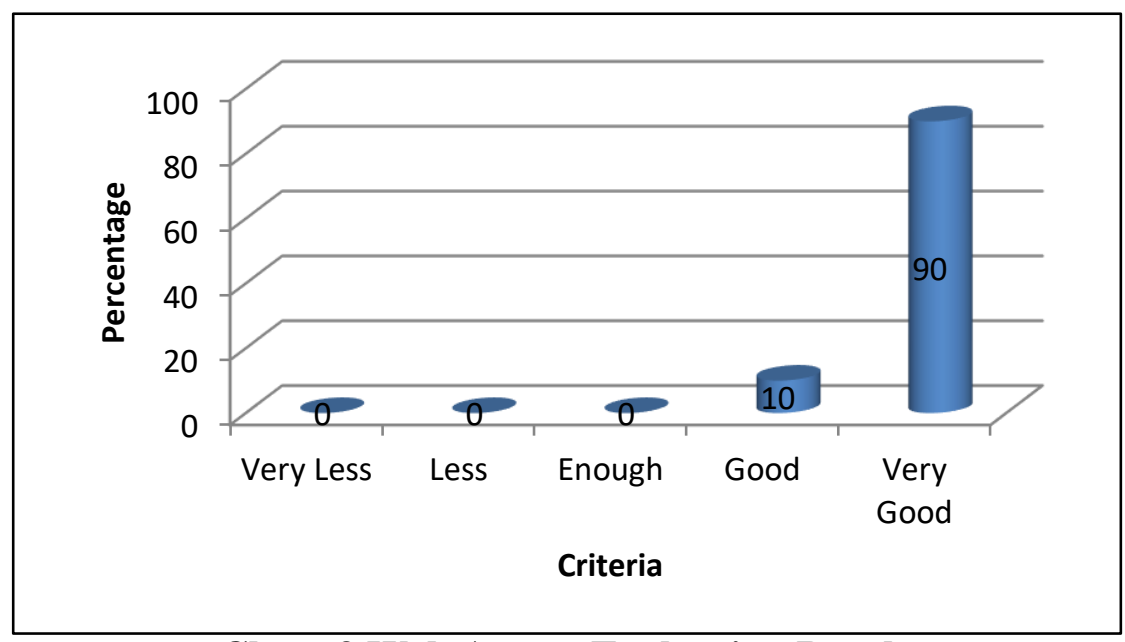

Chart 3.Web Aspect Evaluation Result

The result of a media expert's evaluation categorizes both the display and web system aspects as "good." The display aspect evaluation result (as shown in Table 3) is 4, 07, while the web system evaluation result (as shown in Table 4) is 4, 10. The evaluation result indicated that the web-based English Proficiency test is feasible for product trials.

\section{Product Trial Results}

The product trials consist of one-on-one trials, small group trials, andfield trials. The one-on-one trial is a step in identifying the fundamental problems in the developed 
product; therefore, the issues can be reduced in the subsequent trial. The one-on-one trial is a step in identifying the fundamental problems that occurred; therefore, the problems can be reduced in the subsequent trial. In this trial, the research subjects are instructed to evaluate the display and the web system aspects through the questionnaire. The scores obtained from both display and the web system aspects are 3,51 (good) and 3,50 (good).

Meanwhile, in the small group trial, the results are 4, 24, and 4, 36 for both the display and the web system aspects. The one-on-one trial and small group trial wereincluded in the "good" category. Therefore, the web-based English proficiency test can be applied in the field trial.

Furthermore, the field trial concludes a series of product trials conducted in this research. This trial is conducted to determine the feasibility of the produced product. As with prior trials, data on product quality were gathered at this stage using Likert scale questionnaires and in-depth interviews with trial subjects.This trial discloses information about the display and the web system aspects. The data and information gathered during this trial phase are used to revise any remaining product components. Additionally, questionnaires and interviews were used to complement or reinforce data collected from the trial subjects through a Likert scale. It is expected that this trial will result in a high-quality product that is acceptable for use as an online test system. The description of the field trial is shown in the following tables.

Table 5. Display Aspect Evaluation

\begin{tabular}{clrc}
\hline No. Indicators & \multicolumn{1}{c}{$\begin{array}{c}\text { Average } \\
\text { Scores }\end{array}$} & Criteria \\
\hline General Display & & \\
1 & The Interesting home page design & 4,44 & Very Good \\
2 & Color selection accuracy on the login page & 3,44 & Very Good \\
3 & Text color selection accuracy & 4,21 & Good \\
4 & Font selection accuracy & 4,06 & Good \\
5 & Color compatibility of the button with the & 4,24 & Very Good \\
& background & & \\
6 & Button consistency & 3,91 & Good \\
7 & Button size accuracy & 4,06 & Good \\
8 & Button location accuracy & 4,12 & Good \\
9 & The attractiveness of the menu display & 4,26 & Very Good \\
The Question Display & & \\
10 & The Interesting home page design & 4,38 & Very Good \\
11 & Color selection accuracy on the login page & 4,47 & Very Good \\
12 & Text color selection accuracy & 4,18 & Good \\
\hline
\end{tabular}




\begin{tabular}{llcc}
\hline 13 Font selection accuracy & 4,44 & Very Good \\
14 Color compatibility of the button with the & 4,29 & Very Good \\
background & $\mathbf{5 9 , 5 0}$ & \\
Total & $\mathbf{4 , 2 5}$ & Very Good \\
Average Score
\end{tabular}

Based on the table above, the field trial result is 4,25 . This score is categorized into "very good."Furthermore, the indicators of display aspect evaluation consist of 14 indicators. There are eight indicators $(57,14 \%)$ that are assessed as "very good," and six indicators $(42,86 \%)$ are considered as "good." The following chart describes the result.

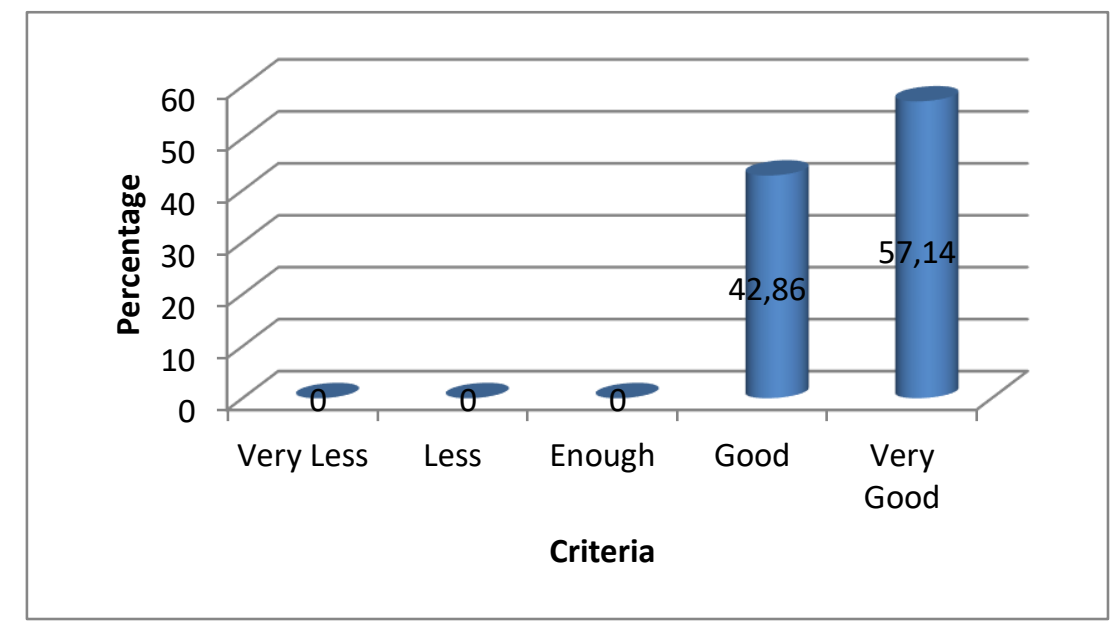

Chart 4.Media Aspect Evaluation Result

Meanwhile, in the web system aspect, the field trial result is 4,33 , which is categorized into "very good." The result can be seen in the following table.

Table 6. Web System Aspect Evaluation

\begin{tabular}{clcc}
\hline No. & \multicolumn{1}{c}{ Indicators } & $\begin{array}{c}\text { Average } \\
\text { Scores }\end{array}$ & Criteria \\
\hline 1 & Ease of using the system & 4,32 & Very Good \\
2 & Complete menu to support operations & 4,38 & Very Good \\
3 & Ease of selecting the menu on the system & 4,41 & Very Good \\
4 & Ease of interacting with the system & 4,68 & Very Good \\
5 & Easy to understand navigation structure & 4,38 & Very Good \\
6 & Key function speed (navigation performance) & 4,26 & Very Good \\
7 & Button reaction accuracy (navigator buttons) & 3,97 & Baik \\
8 & Easy to use navigation for links between & 4,35 & Very Good \\
& components & 4,24 & Very Good \\
9 & System security & 4,26 & Very Good \\
10 & Sufficient time during the exam & $\mathbf{4 3 , 2 6}$ & \\
Total & $\mathbf{4 , 3 3}$ & Very Good \\
Average Score & & \\
\hline
\end{tabular}


Based on the table, there are ten indicators of the web system aspect. From those indicators, nine indicators (90\%) are assessed as "very good," and one indicator $(10 \%)$ is setas "good". The analysis result is shown in the following chart.

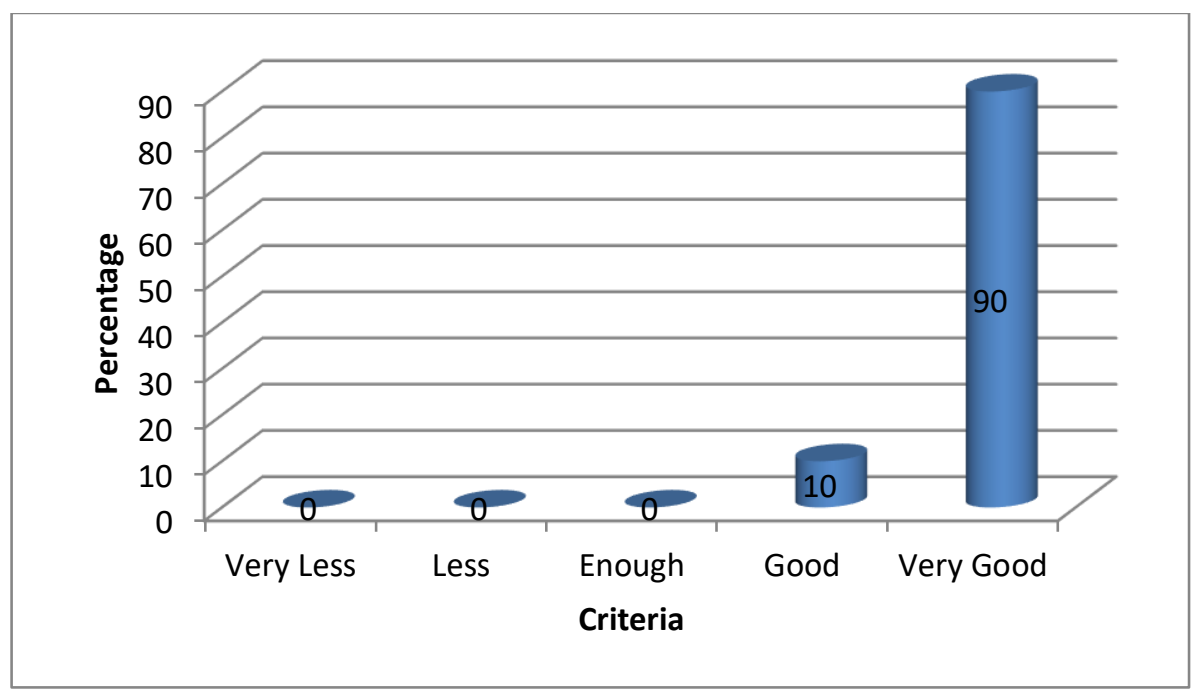

\section{Chart 5.Web Aspect Evaluation Result}

Each of Tables 5 and 6 received a score of 4.25 and 4.33 for the display and system aspects, respectively. Overall, the average score was 4.29. This score is included in the "very good" criteria based on the qualitative data conversion. Therefore, Tables 5 and 6 demonstrated that the web-based English proficiency test deserved a web-based test.

\section{Discussion}

Web or the Internet was a reliable source of information for many of us. As a learning tool to support the program and deliver online learning instruction, the web has become increasingly popular in the academic context. The web-based test format provided increased opportunities for innovation in the assessment. It was created to align with the powerful assessment concept by selecting the question format, the approach to philosophy embedded in the question, and the cognitive level of the question. When used correctly, online tests can be a valuable tool for assessing students' English proficiency.

The outcome of this research is the web-based English Proficiency Test model. Due to a series of evaluation processes, such as material and media evaluation and trial stages ranging from one-on-one trials to small group trials to field trials, this product is suitable for English Proficiency test media for the English Program at IAIN Sultan Amai Gorontalo.

Before coming on the trial processes, the test items were validated by the material expert. The aspects assessed were material, construction, and language. The validation 
result was 4.23. The test items were valid as the English proficiency test based on the development. After the validation process was done, the researcher conducted the product trial.

The test trials, material evaluations, media evaluations, one-on-one trials, small group trials, and field trials demonstrated the product's feasibility. The material evaluations achieved a score of 4.23 (Very Good), the display aspect received a score of 4.07 (Good), and the system aspect received 4.10 (Good).Meanwhile, the results of the field trials evaluation were 4.25 (excellent) in terms of the appearance aspect and 4.33 (excellent) in terms of the system aspect (very good). According to the defined product quality criteria, the product generated declared feasible if the aspects of the product that have been evaluated receive a minimum value of "B" or "Good." According to the findings, this product deserves to be used as a web-based English Proficiency test medium for the English Program at the IAIN Sultan Amai Gorontalo's English Education Department.

The final product of this research is a web-based test of English Proficiency. It can be accessed anytime through a computer and smartphone with an internet connection. This tool enables the students to have better language competency (Hasan et al., 2021) therefore, a web-based test developed in this research optimize the smartphone during the product trials. The more effective way is using smartphones because the students now cannot be separated from those tools.

According to the field trial findings, it could be seen that the trial subjects were incredibly enthusiastic about the product, likewise with the results of interviews conducted on the trial subjects after the field trial process was carried out. They stated that this web-based system was feasibly used for the English Program.In line with this result, Hajebi found that learners' perception improves by incorporating web-based instruction in language learning classrooms (Hajebi et al., 2018). However, the use of the web-based was different, but it indicated that the assessment process permitted the students to have an accurate score.

The Web-based of English Proficiency test provided more accurate and fast feedback. The same result was found by Pertamasari, whoused the web-based in the learning processes. The study revealed that the application generated individual assignments, marked student responses, supplied students with rapid feedback, and recorded student activities (Permatasari et al., 2019). Moreover, Diaz (2018) stated that 
the Web-based test guaranteed immediate results and feedback, provided a more accurate assessment of the test taker's ability, secured improved test security, and created a more positive attitude to tests overall. According to the Cong-Lem the role of language instructors in web-based technology implementation was also found to be crucial, e.g., monitoring L2 learners' learning progress and providing feedback (CongLem, 2018). Therefore, in this case, the lecturers were easy to control the students' improvement.

Compared to other research, this Web-based of English Proficiency test assessed three skills: listening, reading, and structure. Meanwhile, the same research only assessed one skill (Azmi, 2020; Rokhaniyah \& Putra, 2021) that evaluated the reading skill and (Cong-Lem, 2018) that focused on assessing the students' speaking performance. However, these studies reflected that Web-based development could measure English proficiency.

The disadvantages of this product could only be accessed online by students connected to a reliable internet connection. The available bandwidth/availability of the internet network also impacted the smoothness of access to the web-based test, making the online testing process more difficult. Other studies also revealed that Raja \& Nagasubramani (2018) found that the online test system depended on an internet connection and software. If any of these components failed, learners could not take the exam.

\section{CONCLUSION}

Administering a Web-based test to students to evaluate their academic abilities is becoming more prevalent in the digital realm. Students can complete the test online at their own pace and on their devices, regardless of their location. All required is an internet connection and a web browser to function correctly.

The Web-based English proficiency test model is feasible based on the research result. The feasibility is based on the evaluation results of material assessment experts and media experts, who evaluated the material aspect "very good" and the display and system characteristics as "good." Meanwhile, the evaluation results of the trial subjects in the field trialare 4.25 (very good) for the appearance aspect and 4.33 for the system aspect (very good). 
It is suggested that: a) other studies may consider conducting additional research to develop a web-based English Proficiency test by more thoroughly investigating the product's effectiveness using experimental methodology; b) lecturers are recommended to use this product as listening, reading, and English structure tests in the final examination.

\section{REFERENCES}

Abass, O. A., Olajide, S. A., \& Samuel, B. O. (2017). Development of web-based examination system using open source programming model. Turkish Online Journal of Distance Education, 18(2), 30-42. https://doi.org/10.17718/tojde.306555

Azmi, U. (2020). Developing web-based reading tests for the students of English language education. 1(2), 92-104.

Barekar, P., Deshmukh, S., Satone, A., Maity, S., Bhandarkar, K., \& Dhote, D. (2021). Web based test system for online examination. International Journal of Future Generation Communication and Networking, 14(1), 2517-2527.

Borg W.R., G. M. (1988). Education research and development. New York: Longman

Ciptaningrum, D. S. (2017). The development of the survey of technology use, teaching, and technology-related learning experiences among pre-service English language teachers in Indonesia. Journal of Foreign Languange Teaching and Learning, 2(2), $11-26$.

Cong-Lem, N. (2018). Web-Based Language Learning (WBLL) for enhancing L2 speaking performance: A Review. Advances in Language and Literary Studies, 9(4), 143. https://doi.org/10.7575/aiac.alls.v.9n.4p.143

Diaz Maggioli, G. H. (2018). Web-Based Testing. The TESOL Encyclopedia of English Language Teaching, 1-6. https://doi.org/10.1002/9781118784235.eelt0362

Hajebi, M., Taheri, S., Fahandezh, F., \& Salari, H. (2018). The role of web-based language teaching on vocabulary retention of adult pre-intermediate EFL learners. Journal of Language Teaching and Research, 9(2), 372. https://doi.org/10.17507/jltr.0902.20

Hasan, J. R., Hasanuddin, Malik, H., Machmud, K., \& Habibie, A. (2021). Designing a specific EFL writing rubric for a genre-based writing assessment. International Journal of Education and Social Science Research, 04(03). https://doi.org/10.37500/ijessr.2021.4327

Kessler, G. (2018). Technology and the future of language teaching. Foreign Language Annals, 51(1), 205-218. https://doi.org/10.1111/flan.12318

Mcintire, S . A ., Miller, L.A. 2000. Foundation of psychological testing. McGrawHill Companies. Boston.

Permatasari, G. A., Ellianawati, E., \& Hardyanto, W. (2019). Online Web-Based Learning and Assessment Tool in Vocational High School for Physics. Jurnal Penelitian \& Pengembangan Pendidikan Fisika, 5(1), 1-8. https://doi.org/10.21009/1.05101

Qu, W., \& Zhang, C. (2013). The analysis of summative assessment and formative assessment and their roles in college English assessment system. Journal of Language Teaching and Research. https://doi.org/10.4304/jltr.4.2.335-339 
Rokhaniyah, H., \& Putra, O. V. (2021). Developing web-based online test system to boost. 9(2), 235-244. 